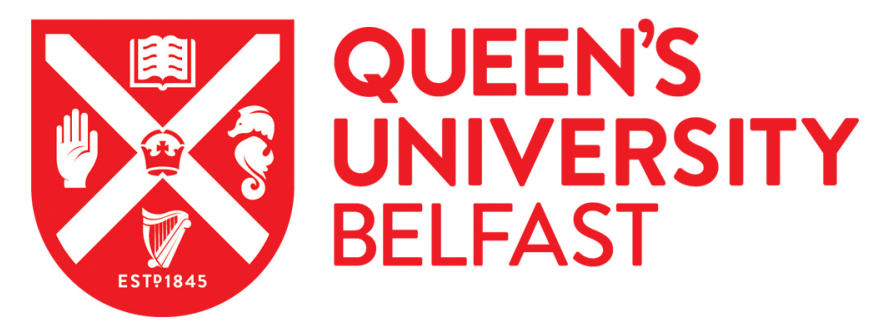

\title{
Engineered Spider Silk Protein-Based Composites for Drug Delivery
}

Hardy, J. G., Leal-Egana, A., \& Scheibel, T. R. (2013). Engineered Spider Silk Protein-Based Composites for Drug Delivery. Macromolecular Bioscience, 13(10), 1431-1437. https://doi.org/10.1002/mabi.201300233

\author{
Published in: \\ Macromolecular Bioscience
}

\section{Document Version:}

Peer reviewed version

\section{Queen's University Belfast - Research Portal:}

Link to publication record in Queen's University Belfast Research Portal

\author{
Publisher rights \\ (c) 2013 WILEY-VCH Verlag GmbH \& Co. KGaA, Weinheim
}

This is the peer reviewed version of the following article: Hardy, JG, Leal-Egana, A \& Scheibel, TR 2013, 'Engineered Spider Silk ProteinBased Composites for Drug Delivery' Macromolecular bioscience, vol 13, no. 10, pp. 1431-1437, which has been published in final form at 10.1002/mabi.201300233. This article may be used for non-commercial purposes in accordance with Wiley Terms and Conditions for SelfArchiving.

\section{General rights}

Copyright for the publications made accessible via the Queen's University Belfast Research Portal is retained by the author(s) and / or other copyright owners and it is a condition of accessing these publications that users recognise and abide by the legal requirements associated with these rights.

\section{Take down policy}

The Research Portal is Queen's institutional repository that provides access to Queen's research output. Every effort has been made to ensure that content in the Research Portal does not infringe any person's rights, or applicable UK laws. If you discover content in the Research Portal that you believe breaches copyright or violates any law, please contact openaccess@qub.ac.uk. 
MBS ((please add journal code and manuscript number, e.g., DOI: 10.1002/mbs.201100001)) Article type: Communication

\section{Engineered spider silk protein-based composites for drug delivery ${ }^{1}$}

John G. Hardy, Aldo Leal-Egaña and Thomas R. Scheibel*

Dr. J. G. Hardy, Dr. A. Leal-Egaña, Prof. T. R. Scheibel

Lehrstuhl Biomaterialien, Fakultät für Ingenieurwissenschaften, Universität Bayreuth, Universitätsstraße 30, 95447 Bayreuth, Germany

E-mail: thomas.scheibel@bm.uni-bayreuth.de

Silk protein-based materials are promising materials for the delivery of drugs and other active ingredients, due to their processability, biocompatibility and biodegradability. The preparation of films composed of an engineered spider silk protein (eADF4(C16)) in combination with either a polyester (polycaprolactone) or a polyurethane (pellethane ${ }^{\circledR}$ ), and their physicochemical properties are described. The release profiles of low molecular weight model drugs are affected by both the film composition and the presence of enzymes, and release can be observed over a period of several weeks. Such silk-based composites have potential as drug eluting biocompatible coatings or implantable devices.

\section{Introduction}

Implantable biodegradable biomaterials are attractive for the manufacture of devices for the controlled delivery of drugs and moreover as tissue scaffolds for biomedical applications. ${ }^{[1-11]} \mathrm{A}$ reliable and controllable release profile is important for a drug to have its optimal effect and minimize side effects, ${ }^{[12]}$ and composite materials based on silk proteins $^{[13,14]}$ are attractive drug carriers due to their biocompatibility and highly tunable

\footnotetext{
${ }^{1}$ Supporting Information is available at Wiley Online Library or from the author.
} 
morphologies with biomimetic mechanical properties. In this context, a range of such materials have been investigated in recent years, typically composed of Bombyx mori silkworm fibroin ${ }^{[15]}$ and polymers (such as albumin, ${ }^{[16]}$ hyaluronic acid, ${ }^{[17]}$ polyethylene glycol, ${ }^{[18]}$ or polyvinyl alcohol ${ }^{[19]}$ ) for the release of a variety of drugs of either low or high molecular weights. ${ }^{[13]}$

Silkworms are not the only creatures to produce task-specific silk-based materials, ${ }^{[20]}$ indeed, web-weaving spiders (e.g. Araneus diadematus or Nephila clavipes) are capable of producing silk fibers with impressive mechanical properties ${ }^{[21]}$ that have been used by humans in certain parts of the world as fishing nets or wound dressings for centuries. ${ }^{[22]}$ Although it is possible to harvest natural spider silk fibers this is an incredibly time consuming and expensive process, and attempts to farm spiders on an industrial scale have as yet been unsuccessful. However, the determination of the primary structures of natural spider silk proteins has recently allowed the production of spider silk-like proteins using recombinant DNA technology on a scale large enough for industrial applications to be realizable. ${ }^{[23-31]}$ Recombinant DNA technology has also been used to prepare chimaeric/hybrid proteins incorporating silkworm silk-like or spider silk-like sequences and other sequences that enhance the proteins solubility, ${ }^{[32,33]}$ or improve

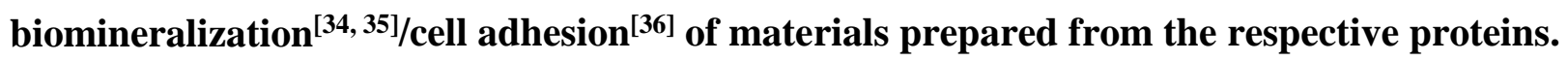

We are particularly interested in the silk proteins produced in the major ampullate silk glands of A. diadematus spiders, and have previously reported the production of major ampullate mimetic silk proteins engineered for production via high density fermentation in Escherichia coli bacteria, namely, eADF-3((AQ)12) and eADF-4(C16). ${ }^{[37,38]}$ Once purified, we can process these proteins using either aqueous or organic solvents into a number of different materials morphologies, including fibers, films, hydrogels, capsules and particles, that would be of interest for both drug delivery and tissue engineering applications. ${ }^{[22,25,39]}$ We have previously investigated the use of microparticles of eADF-4(C16) for the delivery of model low molecular weight drugs, ${ }^{[40-42]}$ and moreover that crosslinking the proteins in the particles prolonged the duration of drug delivery. ${ }^{[42]}$ We have also demonstrated it to be possible to utilize different solvents to prepare films composed of eADF-4(C16) with 
tunable (chemical, ${ }^{[36]}$ mechanical ${ }^{[43,44]}$ and topographical) ${ }^{[43,44]}$ properties that are known to influence the adhesion of cells on their surfaces. ${ }^{[45]}$ Herein we describe the preparation of films composed of eADF4(C16) and one of two biodegradable polymers (either polycaprolactone $(\mathrm{PCL})^{[46]}$ or pellethane ${ }^{\circledR}(\mathrm{TPU})^{[47,48]}$ ) that have been widely investigated for a variety of biomedical applications. We report their physical properties, their loading with positively charged small molecules (methyl violet or ethacridine lactate), the subsequent release of the cationic molecules that act as models for cationic drugs such as the antiphyschotic haloperidol for which long term delivery over the period of weeks is particularly attractive, and finally, the adhesion of cells to the surfaces of the films. Experimental Section

Materials

The recombinantly produced protein was based on the consensus motifs of the repetitive core domains of one of the major ampullate silk fibroins of the garden cross spider (Aranaeus diadematus fibroin 4). The recombinant protein is composed of sixteen repeats of the polypeptide module C (amino acid sequence:

GSSAAAAAAAASGPGGYGPENQGPSGPGGYGPGGP), and is referred to hereafter as eADF-4( $\left.\mathrm{C}_{16}\right)$. Production and purification of eADF-4(C $\left.\mathrm{C}_{16}\right)$ was carried out as described previously. ${ }^{[37]}$ PCL (CAPA 6800, average molecular weight $80 \mathrm{kDa}$ ) was obtained from Perstorp UK Ltd (UK) and TPU (Pellethane 2363-80A, medical grade) was obtained from Dow Chemical Company (US), and both were used as supplied. Unless otherwise stated, all other chemicals were obtained from Sigma-Aldrich Chemie GmbH and used as supplied.

\section{Film preparation}

Optically clear solutions of the protein eADF- $4\left(\mathrm{C}_{16}\right)$ and/or the biodegradable polymers dissolved in hexafluoroisopropanol (HFIP) were cast onto a flexible Teflon substrate. The solvent was allowed to evaporate over a period of 24 hours in a fume hood and are hereafter referred to as 'as cast'. Films that were subsequently immersed in anhydrous methanol for 1 hour prior to drying for 
24 hours are hereafter referred to as 'methanol treated'. The thickness of the films was determined with high precision digital calipers (Bochem, Germany). The proteins and polymers were phase separated in the films. Optical microscopy (Leica DFC295 camera mounted on an inverse microscope, Leica DMIL LED microscope, Germany) was used to determine the component constituting the continuous phase of the films. For full experimental details refer to the supplementary information.

\section{Thermogravimetric analysis (TGA)}

Analyses were carried out with a Mettler Toledo TGA/SDTA 851E thermobalance (Mettler Toledo GmbH, Giessen, Germany). For full experimental details refer to the supplementary information.

\section{X-ray diffraction (XRD)}

XRD spectra were recorded on a Bruker D8 Advance X-ray diffractometer and the XRD patterns were analyzed using Jade 9 XRD Pattern Processing software (Materials Data, Inc., California). For full experimental details refer to the supplementary information.

\section{Tensile Testing}

The Young's modulus, tensile strength and elongation at break were carried out with an Instron Universal Testing Machine (model 5565, Instron Deutschland GmbH, Germany). For full experimental details refer to the supplementary information.

\section{Water contact angle measurements}

Measurements were carried out with a high-speed contact angle measurement device (OCAH 230 video-based semi-automatic contact angle measurement device supplied by Dataphysics GmbH, Germany). For full experimental details refer to the supplementary information.

\section{In vitro degradation studies}

The in vitro degradation of the films was carried out with minor modifications to our previously described methodology. ${ }^{[40]}$ For full experimental details refer to the supplementary information. 


\section{Drug loading and release studies}

Films (25 mg) were loaded with model low molecular weight drugs (methyl violet or ethacridine lactate $)^{[40]}$ by incubation of the films for 15 minutes in a saturated solution of the model drugs in PBS. Drug loaded films were suspended in PBS and incubated at $37^{\circ} \mathrm{C}$. The solvent was periodically removed from each sample and replaced with fresh PBS. The drug content in the medium was analyzed using UV-Vis spectrometry (SpectraMax M3 Multi-Mode Microplate Reader). For full experimental details refer to the supplementary information.

\section{In vitro cell adhesion studies}

Cell adhesion studies were carried out in line with our previously described methodology. ${ }^{[36]}$ The fibroblast cell line (M-MSV-BALB/3T3, mouse embryo fibroblasts) was sourced from the European Collection of Cells (United Kingdom). Cell adhesion was determined with the AlamarBlue ${ }^{\circledR}$ cell viability assay (Cell Titer-Blue, Promega, USA) according to the protocol of the supplier. For full experimental details refer to the supplementary information.

\section{Results and Discussion}

\section{Film preparation and characterization}

The compositions of the films described herein are found in Table 1. All films had thicknesses of ca. $100 \mu \mathrm{m}$, and would therefore not be expected to be encapsulated by a very thick foreign body capsule in vivo. ${ }^{[49]}$ Thermogravimetric analysis revealed that 'as cast' films contained residual HFIP which could be removed by immersion of the films in methanol (Figures S1-S9). The silk component of the 'as cast' films was water soluble due to its $\alpha$-helix rich nature, confirmed by X-ray diffraction (XRD) peaks at $2 \theta=14.4^{\circ}$ and $19.4^{\circ}$, whereas the silk component of 'methanol treated' films was insoluble in water due to its $\beta$-sheet rich nature, as confirmed by XRD peaks at $2 \theta=16.7^{\circ}, 19.9^{\circ}, 24.0^{\circ}$ and $31.8^{\circ}$, all of which are in agreement with the literature. ${ }^{[50-53]}$ Films incorporating PCL had characteristic XRD peaks at $2 \theta=21.5^{\circ}$ and 
$23.6^{\circ}$, in line with those reported in the literature for PCL, ${ }^{[54,55]}$ whereas the TPU component of any films was predictably amorphous, exhibiting a broad peak at $2 \theta=$ ca. $20^{\circ} .^{[48]}$ The XRD spectra and corresponding d-spacings are displayed in Figures S1-S9. The mechanical properties of the films were assessed via tensile testing, and whilst the addition of the biodegradable polymers was observed to reduce the Young's moduli and tensile strengths of the films relative to the silk alone, their extensibilities were typically improved due to the elastomeric natures of the PCL and TPU respectively (Table 1). The tensile strengths of the films (in the low MPa regime) are similar to that of the basement membrane (ca. $4 \mathrm{MPa}$ ), ${ }^{[56]}$ and would therefore be suitable for subcutaneous implantation.

\section{In vitro degradation studies}

The in vitro degradation of the composite films in PBS or solutions including proteases (elastase and trypsin) was studied. As expected, mass loss in PBS was negligible $(<2 \%)$ as eADF-4(C $\left.\mathrm{C}_{16}\right)$, PCL and TPU are insoluble in water, and hydrolysis of the amides, esters and carbamates in their respective backbones is a very slow process (Figure S10). Logically, mass loss in the presence of elastase and trypsin (Figure 1) was greatest for the films composed solely of eADF-4(C $\left.\mathrm{C}_{16}\right)$, and lower for the films composed solely of PCL or TPU. Mass loss of films composed of mixtures of eADF-4(C $\left.\mathrm{C}_{16}\right)$ with either PCL or TPU, was understandably greatest for films with a higher content of eADF-4(C 16$)$, i.e. PCL-25 and TPU-25, and was diminished by the presence of increasing amounts of PCL or TPU. The composites incorporating PCL were observed to degrade less than those incorporating TPU, which is plausibly due to cleavage of carbamate bonds in the backbone of TPU by trypsin. ${ }^{[57-60]}$ Clearly, we would expect that the degradation of the films in vivo would be markedly slower than that of our in vitro assay, in line with the literature precedent for Nephila clavipes spider silk, ${ }^{[61-64]}$ Bombyx mori silkworm silk, ${ }^{[65,66]}$ $\mathrm{PCL}^{[46,67]}$ or TPU ${ }^{[68-72]}$ respectively. 


\section{Drug loading and release studies}

Loading of the films with model drugs (methyl violet or ethacridine lactate) was achieved simply by their incubation in a saturated solution of the drug in PBS followed by rinsing and drying their surfaces. The cationic drugs interacted preferentially with the polyanionic eADF-4(C 16$)$, instead of the uncharged PCL or TPU with which they would only interact via non-specific hydrophobic interactions, which allowed us to tune the quantity of drug loaded into the films simply by tuning the ratio of eADF-4(C $\left.\mathrm{C}_{16}\right)$ to either PCL or TPU. In this preliminary model study we utilized films of $25 \mathrm{mg}$, allowing us to load up to $8.4 \mu \mathrm{mol}$ of cationic drugs in films composed solely of eADF-4(C16), or other defined amounts in the micromolar regime in the other films (see Table 1). We measured the release of the model drugs over the period of a month (see Figure 2), observing the release of methyl violet to be somewhat faster than for ethacridine lactate (as previously reported). ${ }^{[40]}$ We found that the release of the drug was moderately faster in films incubated in the presence of elastase and trypsin, and that the release profiles could be tuned based upon the composition of the films, with higher quantities of drug released from films with higher contents of eADF-4(C $\left.\mathrm{C}_{16}\right)$, and interestingly, that drug delivery from the films would be effective over the period of several weeks (akin to the release of drugs from Bombyx mori silk-based films) ${ }^{[73,74]}$ that would be particularly attractive for the delivery of cationic antipsychotic drugs such as haloperidol.

\section{In vitro cell adhesion studies}

With a view to the application of such composites as implantable platforms for the controlled delivery of drugs (e.g. as drug eluting implant coatings) in tissues with similar mechanical properties (e.g. subcutaneously, in the vicinity of the basement membrane), ${ }^{[56]}$ we investigated the adhesion of BALB/3T3 mouse fibroblasts to the films compared to a simple control substrate (Nunclon ${ }^{\circledR} \Delta$ surface tissue culture plates) in vitro. ${ }^{[36,45,75]}$ It has been reported that mammalian 
cells prefer to adhere to and proliferate on surfaces with a water contact angle above $40^{\circ} .{ }^{[76-80]}$ We observed the water contact angles of our films to be composition dependent (see Table 1). The PCL composites were the most hydrophilic, more so than either of the constituents alone, suggesting that the eADF-4(C $\left.\mathrm{C}_{16}\right)$ interacts with the PCL via van der Waals interactions with the hydrophobic residues on the backbone of the silk proteins, and displays the hydrophilic residues on the surface of the films. This effect was also observed for the TPU-25 composites, although films with higher contents of TPU were more hydrophobic as TPU is markedly more hydrophobic than PCL. We observed BALB/3T3 mouse fibroblasts to adhere to all of the films (see Table 1 and Figure 3), although there were morphological differences between the cells on the different substrates. On the Nunclon ${ }^{\circledR} \Delta$ surface tissue culture plates the majority of the fibroblasts were spread out and clearly adherent because the hydrophobic surface of the tissue culture plate facilitates the adsorption of cell adhesive ECM proteins (e.g. collagen, fibronectin) from the media via non-specific hydrophobic interactions. On the films composed solely of eADF-4( $\left.\mathrm{C}_{16}\right)$ the fibroblasts were rounded which is indicative of poor cell adhesion because the negatively charged surface of the films hinders the adsorption of ECM proteins from the media, and the interactions between the negatively charged cells and surfaces are weak. Fibroblasts on the films composed of mixtures of eADF- $4\left(\mathrm{C}_{16}\right)$ and PCL or TPU were better spread on films with higher PCL or TPU content. Although we did not observe a linear relationship between water contact angle and cell adhesion relative to the control substrate, we found that the cells preferred to adhere to the more hydrophobic films, an effect which is probably mediated by the adsorption of proteins from the media onto the surface of the films. The film-fibroblast interaction could be improved by modifying the proteinaceous component to display celladhesive motifs (e.g. the RGD peptide) either chemically or recombinantly. ${ }^{[30,36,45,75]}$ 


\section{Conclusion}

Silk protein-based materials are promising materials for the delivery of drugs and other active ingredients. The compositions of the films described herein determines their physical properties, and thereby the release profiles of model drugs, and the adhesion of cells to their surfaces. Such silk-based composites have potential as implantable drug delivery devices for the delivery of cationic antiphyschotic drugs such as haloperidol over the period of weeks or potentially tissue scaffolds, for example as drug eluting biocompatible and biodegradable coatings for biodegradable/bioresorbable implants.

Acknowledgements: We thank the Alexander von Humboldt Foundation for a postdoctoral fellowship for J. G. H, and both the German Research Foundation (Deutsche Forschungsgemeinschaft, DFG SCHE 603/4-3) and the German Federal Ministry of Education and Research (Bundesministerium für Bildung und Forschung, BMBF 13N11340) for financial support for T.R.S. At the University of Bayreuth we thank: Markus Hecht, Christine Köstler, Janine Queren and Alexandra Witt for assistance with film preparation and characterization; Ute Kuhn for assistance with TGA; Roman Kress for assistance with X-ray diffraction, Reiner Giesa for assistance with tensile testing, and Elke Fuchs for assistance with contact angle measurements.

Received: ((will be filled in by the editorial staff)); Revised: ((will be filled in by the editorial staff)); Published online: ((please add journal code and manuscript number, e.g., DOI:

10.1002/macp.201100001)) 
Keywords: biodegradable; biomaterials; coatings; composites; drug delivery systems

Table 1. Film compositions and properties.

\begin{tabular}{|c|c|c|c|c|c|c|c|c|c|}
\hline Film & $\begin{array}{c}\text { Mass Ratio } \\
\text { Protein:Polymer }\end{array}$ & $\begin{array}{c}\text { Continuous } \\
\text { phase }\end{array}$ & $\begin{array}{c}\text { YM } \\
\text { (MPa) }\end{array}$ & $\begin{array}{c}\text { TS } \\
(\mathbf{M P a})\end{array}$ & $\begin{array}{c}E \\
(\%)\end{array}$ & $\begin{array}{c}\text { WCA } \\
\text { (degrees) }\end{array}$ & $\begin{array}{c}\text { Theoretical } \\
\text { maximum } \\
\text { drug load }^{\mathrm{a}} \\
(\mu \mathrm{mol})\end{array}$ & $\begin{array}{c}\text { Cell } \\
\text { adhesion } \\
\text { relative to } \\
\text { Nunclon }{ }^{\circledR} \\
\Delta \text { surface } \\
(\%)\end{array}$ & $\begin{array}{l}\text { S. } \\
\text { I. }\end{array}$ \\
\hline $\begin{array}{l}\text { eADF- } \\
4\left(C_{16}\right)\end{array}$ & 100:0 & $\begin{array}{l}\text { eADF- } \\
4\left(\mathrm{C}_{16}\right)\end{array}$ & $\begin{array}{r}3300 \\
\pm 500\end{array}$ & $52 \pm 3$ & $\begin{array}{c}1.8 \pm \\
0.3\end{array}$ & $\begin{array}{c}57.4 \pm \\
3.3\end{array}$ & 8.4 & $72.0 \pm 8.0$ & $\begin{array}{l}\text { Fig. } \\
\text { S1 }\end{array}$ \\
\hline $\begin{array}{c}\text { PCL- } \\
25\end{array}$ & $75: 25$ & PCL & $\begin{array}{c}82 \pm \\
34\end{array}$ & $3 \pm 1$ & $\begin{array}{c}60 \pm \\
31\end{array}$ & $\begin{array}{c}34.7 \pm \\
2.1\end{array}$ & 6.3 & $64.8 \pm 3.4$ & $\begin{array}{l}\text { Fig. } \\
\text { S2 }\end{array}$ \\
\hline $\begin{array}{c}\text { PCL- } \\
50\end{array}$ & $50: 50$ & PCL & $\begin{array}{c}119 \pm \\
112\end{array}$ & $2 \pm 1$ & $4 \pm 3$ & $\begin{array}{c}40.6 \pm \\
0.9\end{array}$ & 4.2 & $39.2 \pm 2.4$ & $\begin{array}{l}\text { Fig. } \\
\text { S3 }\end{array}$ \\
\hline $\begin{array}{l}\text { PCL- } \\
75\end{array}$ & $25: 75$ & PCL & $\begin{array}{c}177 \pm \\
90\end{array}$ & $5 \pm 2$ & $\begin{array}{c}20 \pm \\
16\end{array}$ & $\begin{array}{c}43.8 \pm \\
0.5\end{array}$ & 2.1 & $60.5 \pm 9.4$ & $\begin{array}{l}\text { Fig. } \\
\text { S4 }\end{array}$ \\
\hline $\begin{array}{c}\text { PCL- } \\
100\end{array}$ & $0: 100$ & PCL & $\begin{array}{c}101 \pm \\
37\end{array}$ & $7 \pm 2$ & $\begin{array}{c}354 \pm \\
275\end{array}$ & $\begin{array}{c}59.9 \pm \\
2.2\end{array}$ & 0 & $\begin{array}{l}92.0 \pm \\
13.8\end{array}$ & $\begin{array}{l}\text { Fig. } \\
\text { S5 }\end{array}$ \\
\hline $\begin{array}{c}\text { TPU- } \\
25\end{array}$ & $75: 25$ & $\begin{array}{l}\text { eADF- } \\
4\left(\mathrm{C}_{16}\right)\end{array}$ & Brittle & Brittle & Brittle & $\begin{array}{c}26.1 \pm \\
3.1\end{array}$ & 6.3 & $40.7 \pm 4.1$ & $\begin{array}{c}\text { Fig. } \\
\text { S6 }\end{array}$ \\
\hline $\begin{array}{l}\text { TPU- } \\
50\end{array}$ & 50:50 & TPU & $64 \pm 7$ & $5 \pm 1$ & $\begin{array}{l}425 \pm \\
244\end{array}$ & $\begin{array}{l}55.8 \pm \\
1.3\end{array}$ & 4.2 & $48.2 \pm 6.1$ & $\begin{array}{l}\text { Fig. } \\
\text { S7 }\end{array}$ \\
\hline $\begin{array}{l}\text { TPU- } \\
75\end{array}$ & $25: 75$ & TPU & $13 \pm 2$ & $10 \pm 6$ & $\begin{array}{l}720 \pm \\
345\end{array}$ & $\begin{array}{c}64.9 \pm \\
0.5\end{array}$ & 2.1 & $55.1 \pm 4.9$ & $\begin{array}{l}\text { Fig. } \\
\text { S8 }\end{array}$ \\
\hline $\begin{array}{l}\text { TPU- } \\
100\end{array}$ & $0: 100$ & TPU & $6 \pm 2$ & $12 \pm 4$ & $\begin{array}{c}958 \pm \\
198\end{array}$ & $\begin{array}{c}93.0 \pm \\
0.4\end{array}$ & 0 & $\begin{array}{l}108.5 \pm \\
3.5\end{array}$ & $\begin{array}{l}\text { Fig. } \\
\text { S9 }\end{array}$ \\
\hline
\end{tabular}

Young's modulus of elasticity (YM); tensile strength (TS); elongation at break (E); Water

contact angle (WCA); a) assuming a specific acid-base interaction between the carboxylic acid

moieties displayed on eADF-4( $\left.\mathrm{C}_{16}\right)$ and the model drugs (i.e. disregarding non-specific

hydrophobic drug-polymer interactions); Supplementary information (S. I.) 


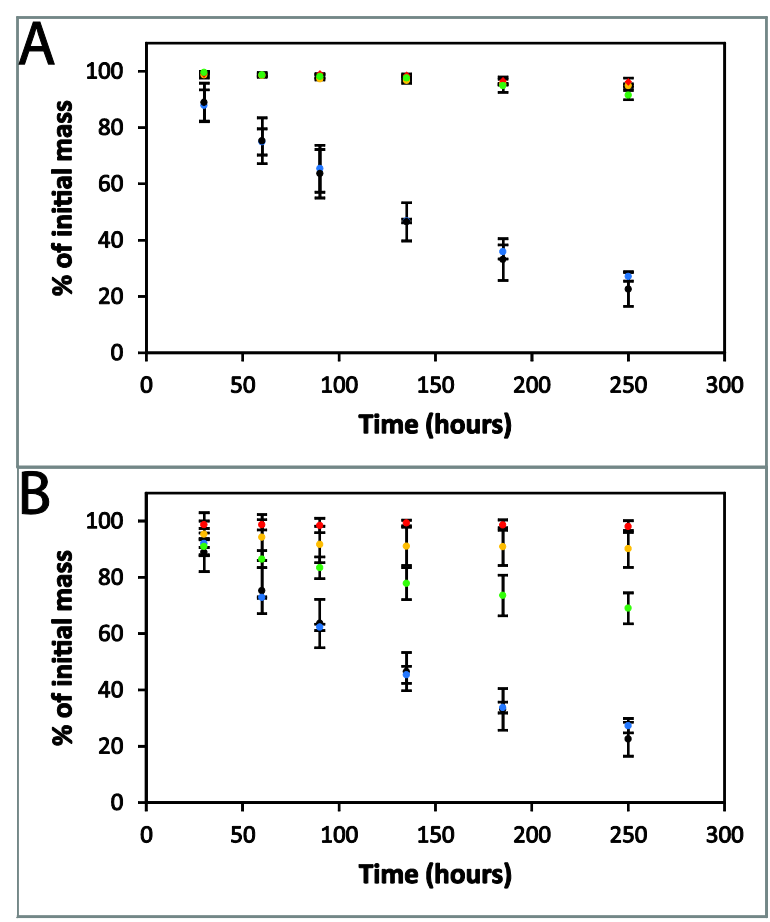

Figure 1. In vitro degradation of the biodegradable films composed of eADF-4(C16) and PCL or TPU in PBS in the presence of elastase and trypsin. A: Black) eADF-4(C16); Blue) PCL-25;

Green) PCL-50; Yellow) PCL-75; Red) PCL-100. B: Black) eADF-4(C16); Blue) TPU-25;

Green) TPU-50; Yellow) TPU-75; Red) TPU-100. 

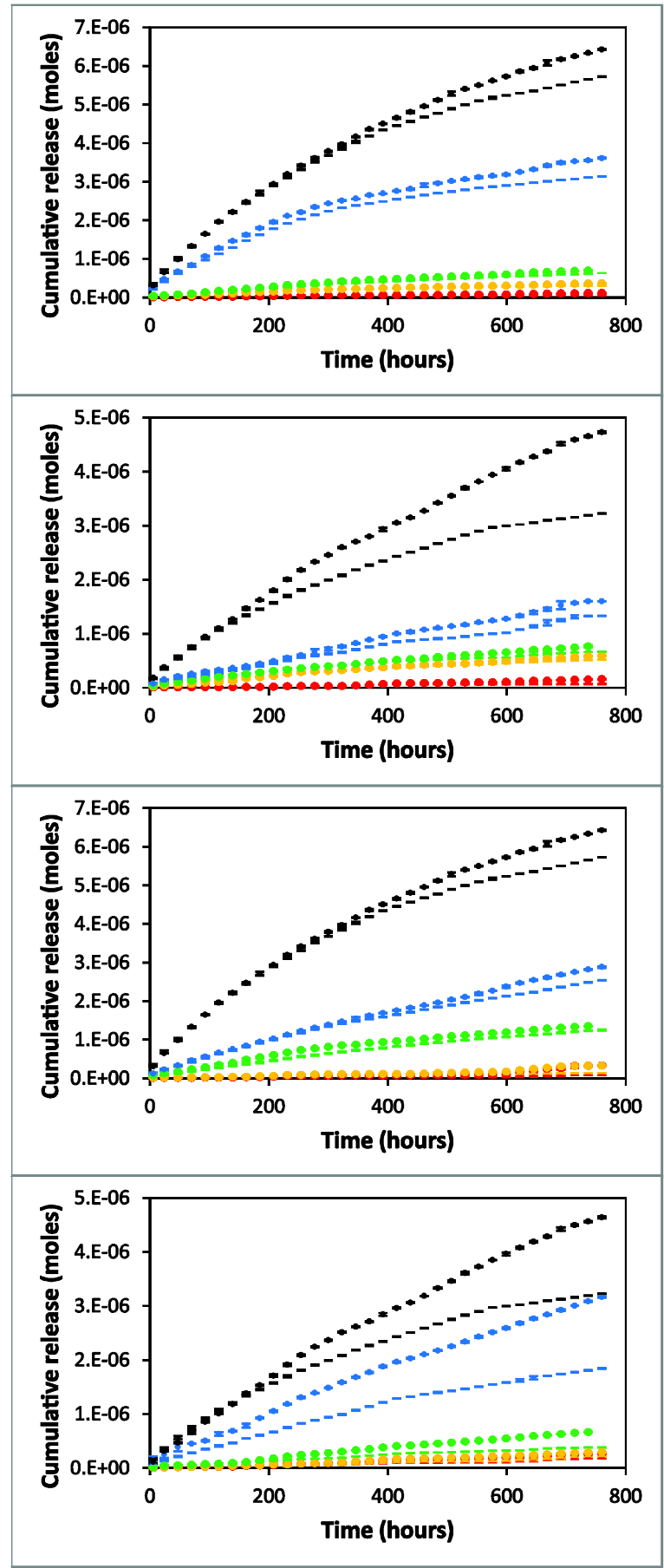
Figure 2. In vitro release of the model drugs from the biodegradable films in the absence or presence of proteases. A) Release of methyl violet from films composed of eADF-4(C16) and PCL. B) Release of ethacridine lactate from films composed of eADF-4(C16) and PCL. Black dashes) eADF-4(C16) without proteases; black circles) eADF-4(C16) with proteases; blue dashes) PCL-25 without proteases; blue circles) PCL-25 with proteases; green dashes) PCL-50 without proteases; green circles) PCL-50 with proteases; yellow dashes) PCL-75 without proteases; yellow circles) PCL-75 with proteases; red dashes) PCL-100 without proteases; red circles) PCL-100 with proteases. C) Release of methyl violet from films composed of eADF4(C16) and TPU. D) Release of ethacridine lactate from films composed of eADF-4(C16) and TPU. Black dashes) eADF-4(C16) without proteases; black circles) eADF-4(C16) with proteases; blue dashes) TPU-25 without proteases; blue circles) TPU-25 with proteases; green dashes) TPU-50 without proteases; green circles) TPU-50 with proteases; yellow dashes) TPU75 without proteases; yellow circles) TPU-75 with proteases; red dashes) TPU-100 without proteases; red circles) TPU-100 without proteases. 
- 14 - 


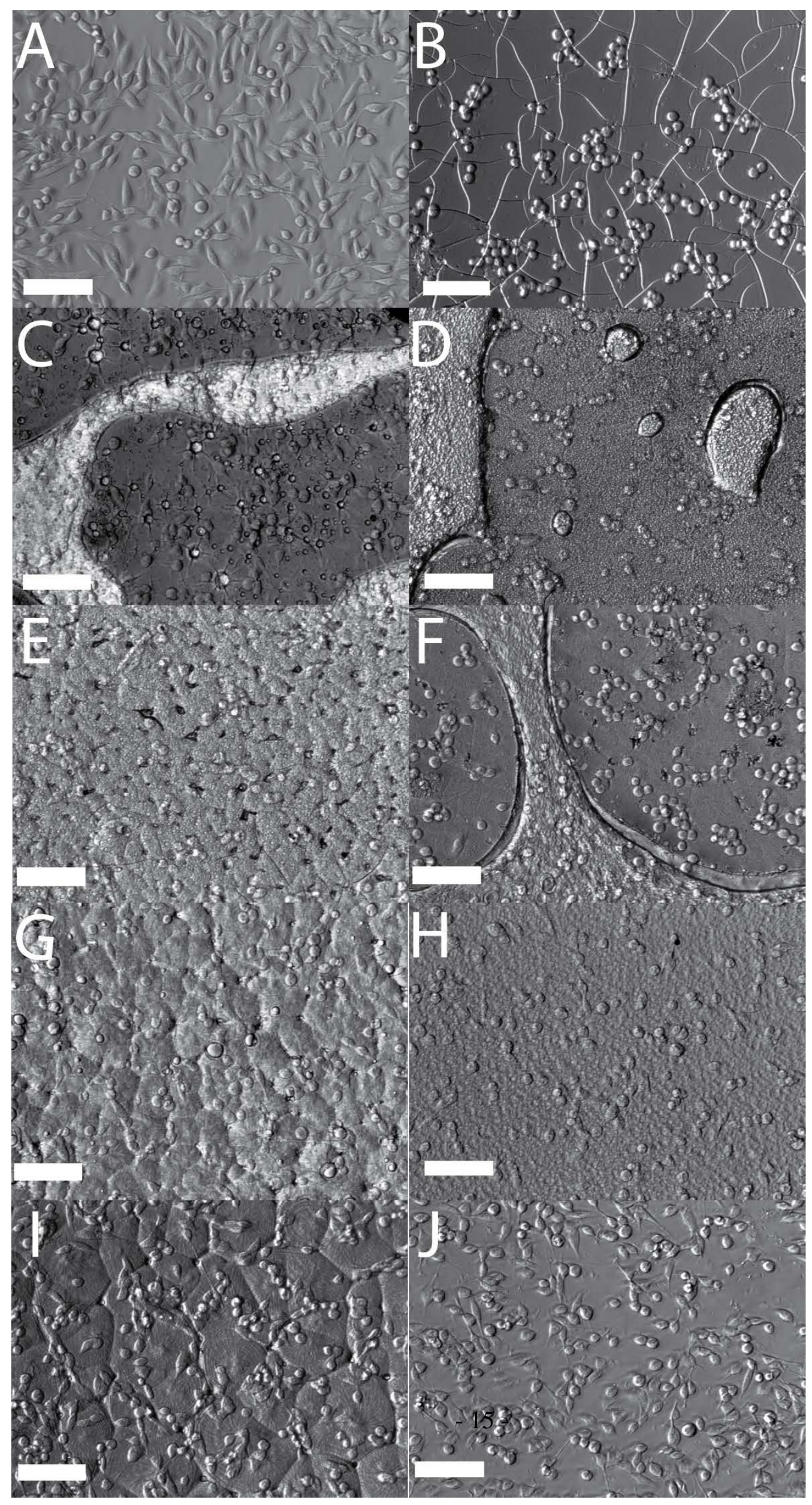


Figure 3. Bright field microscope image of mouse embryo fibroblasts (M-MSV-BALB/3T3) cultured for 6 hours in vitro on the surface of: A) Nunclon ${ }^{\circledR} \Delta$ surface tissue culture plates, B) eADF-4(C16), C) PCL-25, D) TPU-25, E) PCL-50, F) TPU-50, G) PCL-75, H) TPU-75, I) PCL100, J) TPU-100. Scale bars represent $100 \mu \mathrm{m}$. 
Recombinantly produced spider silk protein-based materials are promising for both drug delivery and as tissue scaffolds. Herein we report the preparation of composite films incorporating an engineering spider silk and a biodegradable elastomer (either polycaprolactone or pellethane ${ }^{\circledR}$ ), and their potential as drug eluting biocompatible coatings.

John G. Hardy, Aldo Leal-Egaña and Thomas R. Scheibel*

Engineered spider silk protein-based composites for drug delivery

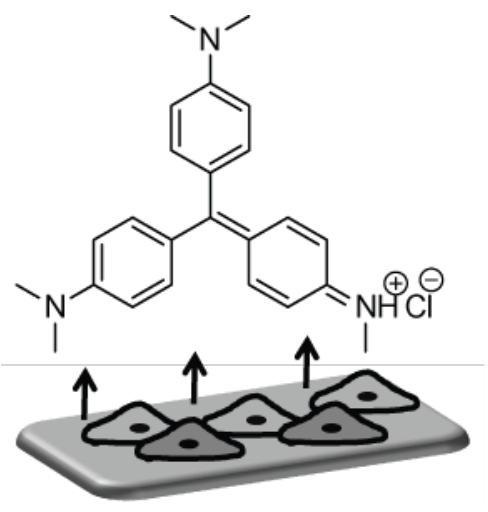


Copyright WILEY-VCH Verlag GmbH \& Co. KGaA, 69469 Weinheim, Germany, 2011.

\section{Supporting Information}

for Abbrev. J. Title, DOI: 10.1002/((please add journal code and manuscript number))

\section{Engineered spider silk protein-based composites for drug delivery}

John G. Hardy, Aldo Leal-Egaña and Thomas R. Scheibel*

\section{Supplementary Experimental Section}

\section{Film preparation}

The protein eADF-4(C $\left.\mathrm{C}_{16}\right)$ and the biodegradable polymers were dissolved in hexafluoroisopropanol (HFIP) at a concentration of $50 \mathrm{~g}$ per liter by shaking in air-tight containers at room temperature until the solutions were optically clear (typically 24 hours). Once clear, solutions were cast onto a flexible Teflon substrate, and the solvent was allowed to evaporate over a period of 24 hours in a fume hood at $20^{\circ} \mathrm{C}$ and a relative humidity of ca. $50 \%$, and are hereafter referred to as 'as cast'. Films that were subsequently immersed in anhydrous methanol for 1 hour prior to drying for 24 hours (in a fume hood at $20{ }^{\circ} \mathrm{C}$ and a relative humidity of ca. 50\%), and are hereafter referred to as 'methanol treated'. The thickness of the films was determined with high precision digital calipers (Bochem, Germany). The proteins and polymers were phase separated in the films. Optical microscopy (Leica DFC295 camera mounted on an inverse microscope, Leica DMIL LED microscope, Germany) was used to determine the component constituting the continuous phase of the films. 


\section{Thermogravimetric analysis (TGA)}

Analyses were carried out with a Mettler Toledo TGA/SDTA 851E thermobalance (Mettler Toledo GmbH, Giessen, Germany). Films were precisely weighed into ceramic crucibles (VWR, Germany), and analyses were carried out under a nitrogen atmosphere (flow rate $100 \mathrm{~mL}$ per minute), over a temperature range between 25 and $800{ }^{\circ} \mathrm{C}$, at a heating rate of $10^{\circ} \mathrm{C}$ per minute. The TGA mass loss profiles are representative of at least 2 samples.

\section{X-ray diffraction (XRD)}

A stack of 3 films were attached to a metal sample holder using adhesive tape. XRD spectra were recorded on a Bruker D8 Advance X-ray diffractometer (CuK ${ }_{\alpha 1}$-beam, $\lambda=154051$ pm, recording angle $6-40^{\circ}(2 \theta)$, angle increment $0.1^{\circ}(2 \theta)$, recording time of 1 minute per angle position). The XRD patterns (plotted as intensity vs 20) were analyzed using Jade 9 XRD Pattern Processing software (Materials Data, Inc., California), and the d-spacings reported have an accuracy typically in the range of $\pm 2 \%$.

\section{Tensile Testing}

The Young's modulus, tensile strength and elongation at break were carried out with an Instron Universal Testing Machine (model 5565, Instron Deutschland GmbH, Germany) equipped with a $10 \mathrm{~N}$ load cell, at a drawing rate of $2 \mathrm{~mm}$ per minute. Prior to testing, the films were stored at 21 ${ }^{\circ} \mathrm{C}$ in an air tight Teflon container (Hagebaumarkt, Germany) in the presence of a glass beaker containing a saturated aqueous solution of calcium nitrate (in order to obtain an atmosphere with a relative humidity of 51\%) for 1 week. Strips of the films with dimensions of $10 \mathrm{~mm}$ x $5 \mathrm{~mm}$ were cut with a razor blade from the films, and the thickness of the films was determined with high precision digital calipers (Bochem, Germany) and is the average of at least 5 positions on the strip. The initial grip separation was set at $5 \mathrm{~mm}$, and the experiments were carried out at $21{ }^{\circ} \mathrm{C}$ in a 
laboratory with a relative humidity of ca. 50\%, and the tensile properties reported are the average of at least 10 measurements.

\section{Water contact angle measurements}

Measurements were carried out with a high-speed contact angle measurement device (OCAH 230 video-based semi-automatic contact angle measurement device supplied by Dataphysics GmbH, Germany). Images of a drop of deionized water $(2 \mu \mathrm{L})$ laid on the surface of the samples were recorded at a frame rate of 360 frames per second, and the contact angles for the droplets were recorded after 3 seconds of contact with the film. Prior to measurement, the films were stored as described in the tensile testing section. The reported values are the average of at least 3 measurements at different positions on a film.

\section{In vitro degradation studies}

The in vitro degradation of the films was carried out with minor modifications to our previously described methodology. ${ }^{[40]}$ Therefore, films (of ca. $20 \mathrm{mg}$ ) were stored for 1 week under high vacuum at $21^{\circ} \mathrm{C}$, after which time their weight was determined on a high precision balance. The films were incubated at $37^{\circ} \mathrm{C}$ in $1.5 \mathrm{~mL}$ phosphate buffered saline (PBS) at a pH of 7.4, in the presence of elastase $(0.8 \mu \mathrm{g})$ and trypsin $(12.5 \mu \mathrm{g})$; whereas, control samples were incubated at 37 ${ }^{\circ} \mathrm{C}$ in $1.5 \mathrm{~mL}$ PBS without enzyme. At specific time points the buffer was removed, the films were carefully washed twice with $1.5 \mathrm{~mL}$ of deionized water, and then dried under high vacuum at 21 ${ }^{\circ} \mathrm{C}$ for 72 hours, after which their weight was determined on a high precision balance. The films were subsequently placed in a fresh solution of buffer (with or without enzymes), and their weight was followed over a period of 250 hours in total. The mass loss profiles are found in the supplementary information and are the average of at least 3 samples. 


\section{Drug loading and release studies}

Films (25 mg) were loaded with model low molecular weight drugs (methyl violet or ethacridine lactate $)^{[40]}$ by incubation of the films for 15 minutes in a saturated solution of the model drugs in PBS at room temperature, rinsed twice with PBS $(0.5 \mathrm{~mL})$, and blotted dry with KimWipes. Drug loaded films were suspended in $1 \mathrm{~mL}$ PBS before incubation at $37^{\circ} \mathrm{C}$. The solvent was periodically removed from each sample and replaced with fresh PBS. The drug content in the medium was analyzed using UV-Vis spectrometry (SpectraMax M3 Multi-Mode Microplate Reader), based upon standard calibration curves for the model drugs. The cumulative model drug release was investigated as a function of incubation time. All experiments were performed in triplicate.

\section{In vitro cell adhesion studies}

Cell adhesion studies were carried out in line with our previously described methodology. ${ }^{[36]}$ The fibroblast cell line (M-MSV-BALB/3T3, mouse embryo fibroblasts) was sourced from the European Collection of Cells (United Kingdom). The cells were cultivated in DMEM (Biochrom AG, Germany) supplemented with $10 \%$ v/v fetal bovine serum (BioChrom AG, Germany), 2mM Glutamax (Gibco, United Kingdom) and $50 \mu \mathrm{g} / \mathrm{ml}$ Gentamycin (Sigma, Germany). Cells were cultured on films cast on 24 well plates (Nunclon ${ }^{\circledR} \Delta$ surface, Denmark). The viability observed for the cells before starting the experiment was determined by the Trypan Blue (Sigma, Germany) exclusion method, and the measured viability exceeded $95 \%$ in all cases. Cell adhesion was determined with the AlamarBlue ${ }^{\circledR}$ cell viability assay (Cell Titer-Blue, Promega, USA) according to the protocol of the supplier. Briefly, 100,000 cells $/ \mathrm{cm}^{2}$ were seeded in wells, and the cells were incubated in $1 \mathrm{~mL}$ of cell culture media per well at $37^{\circ} \mathrm{C}, 95 \%$ humidity, and a $\mathrm{CO}_{2}$ content of 5 \%. After 4 hours the cells were washed gently with PBS to remove non-adherent and/or dead cells, followed by the addition of fresh media $(1 \mathrm{~mL})$ containing $10 \% \mathrm{v} / \mathrm{v}$ of the AlamarBlue ${ }^{\circledR}$ reagent. After 2.5 hours of culture, $100 \mu \mathrm{L}$ of the media containing the AlamarBlue ${ }^{\circledR}$ reagent was removed 
and placed in a 96 well plate, and the fluorescence was measured with a fluorimeter (Mithras LB 940, Berthold Technologies, Germany). Two controls were considered during the measurement of the fluorescence: the first was wells containing media alone (i.e. no cells or AlamarBlue ${ }^{\circledR}$ reagent), which was not fluorescent (data not shown); and the second was wells that contained the AlamarBlue ${ }^{\circledR}$ reagent but no cells (used for baseline correction). Levels of cell adhesion to the various films studied herein are reported relative to Nunclon ${ }^{\circledR} \Delta$ surface, which was assigned an arbitrary value of $100 \%$. 


\section{Supplementary Data Section}
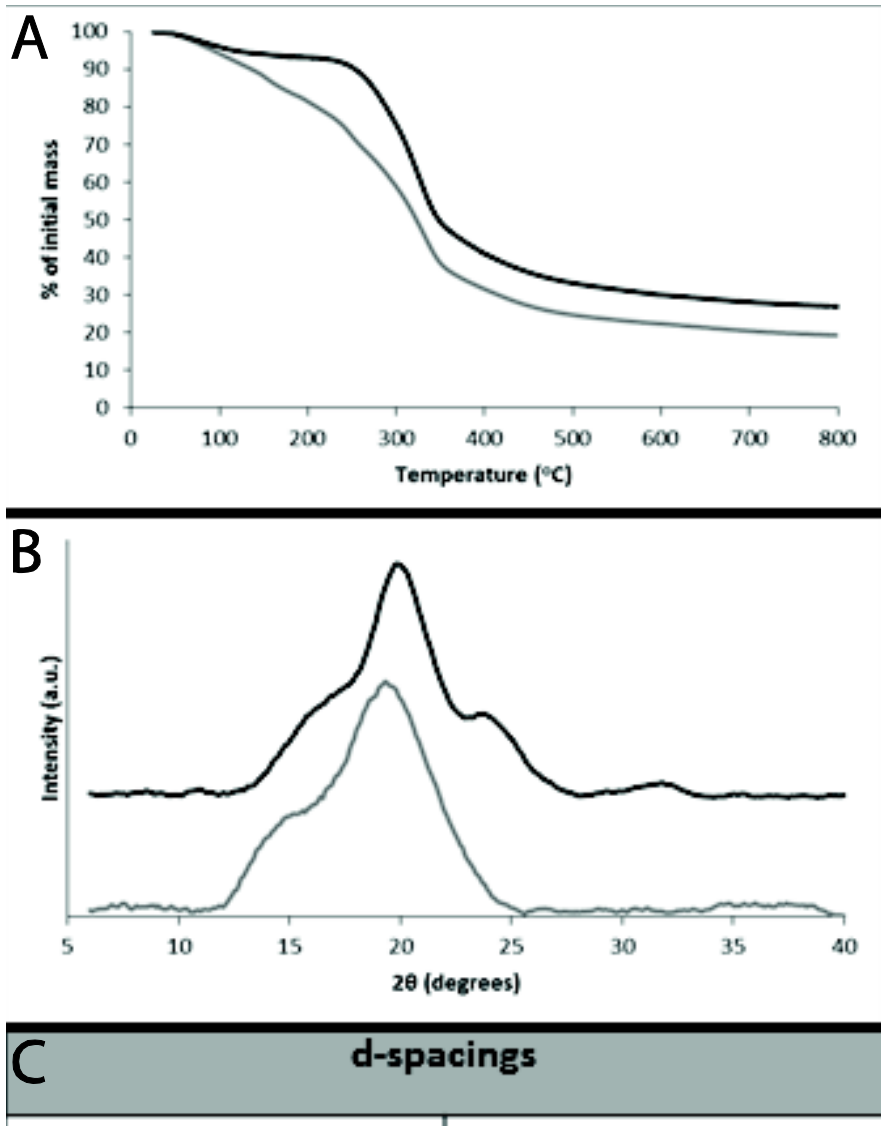

\begin{tabular}{c|c|c|c}
\multicolumn{2}{|c|}{ Films as cast from HFIP } & \multicolumn{2}{|c}{ Methanol treated films } \\
\hline $2 \theta$ & $\begin{array}{c}\text { d-spacing } \\
(\AA)\end{array}$ & $\begin{array}{c}2 \theta \\
\text { (degrees) }\end{array}$ & $\begin{array}{c}\text { d-spacing } \\
(\AA)\end{array}$ \\
\hline 14.41 & 6.14 & 16.71 & 5.30 \\
19.43 & 4.56 & 19.92 & 4.45 \\
& & 31.86 & 2.81 \\
& & & \\
& & &
\end{tabular}

Figure S1. SI for eADF-4 (C16) films. A) TGA mass loss profiles of films as cast (grey line) and after methanol treatment (black line). B) XRD spectra of films as cast (grey line) and after methanol treatment (black line). C) Positions of XRD peaks and d-spacings determined using Jade 9 XRD Pattern Processing software. 
-24 - 

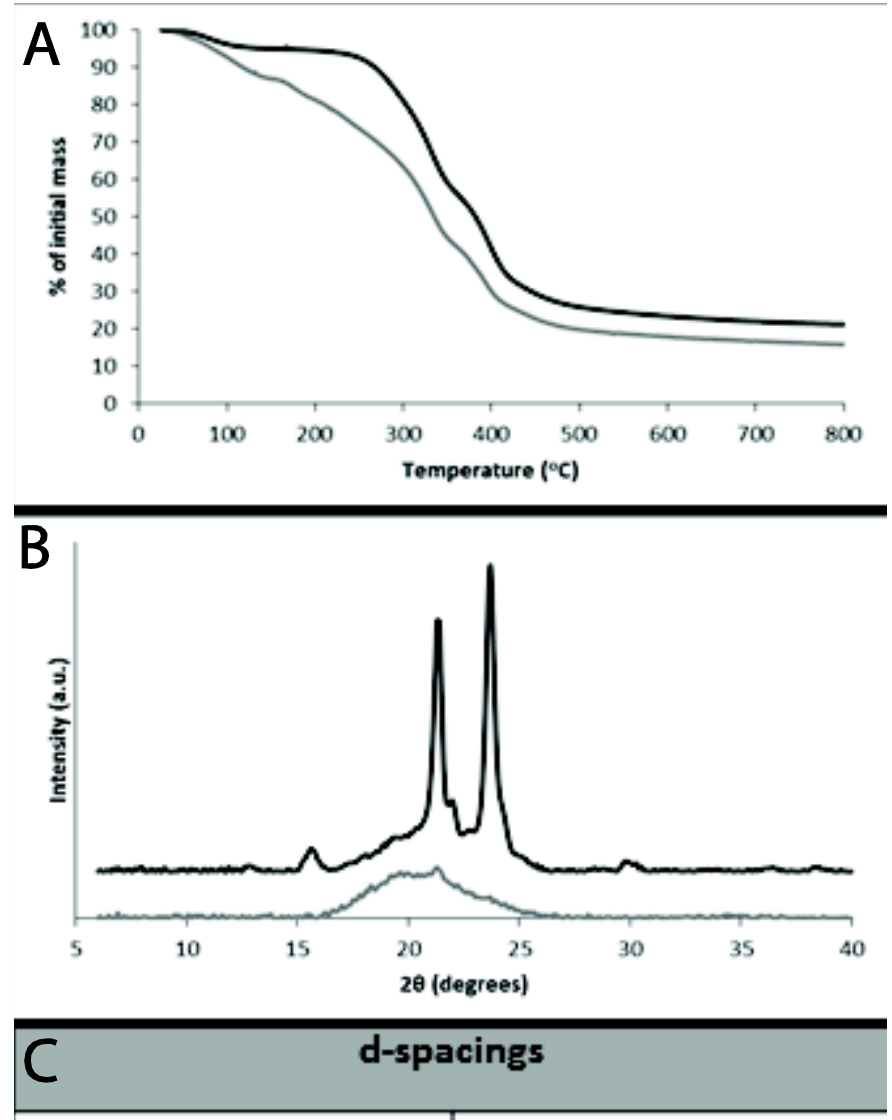

\begin{tabular}{|c|c|c|c}
\multicolumn{2}{|c|}{ Films as cast from HFIP } & \multicolumn{2}{c}{ Methanol treated films } \\
\hline $2 \theta$ & $\begin{array}{c}\text { d-spacing } \\
(\AA)\end{array}$ & $\begin{array}{c}2 \theta \\
\text { (degrees) }\end{array}$ & $\begin{array}{c}\text { d-spacing } \\
(\AA)\end{array}$ \\
\hline 19.42 & 4.57 & 15.63 & 5.67 \\
21.13 & 4.20 & 21.33 & 4.16 \\
23.64 & 3.76 & 23.64 & 3.76 \\
& & 29.76 & 2.99 \\
\hline
\end{tabular}

Figure S2. SI for PCL-25 films. A) TGA mass loss profiles of films as cast (grey line) and after methanol treatment (black line). B) XRD spectra of films as cast (grey line) and after methanol treatment (black line). C) Positions of XRD peaks and d-spacings determined using Jade 9 XRD Pattern Processing software. 

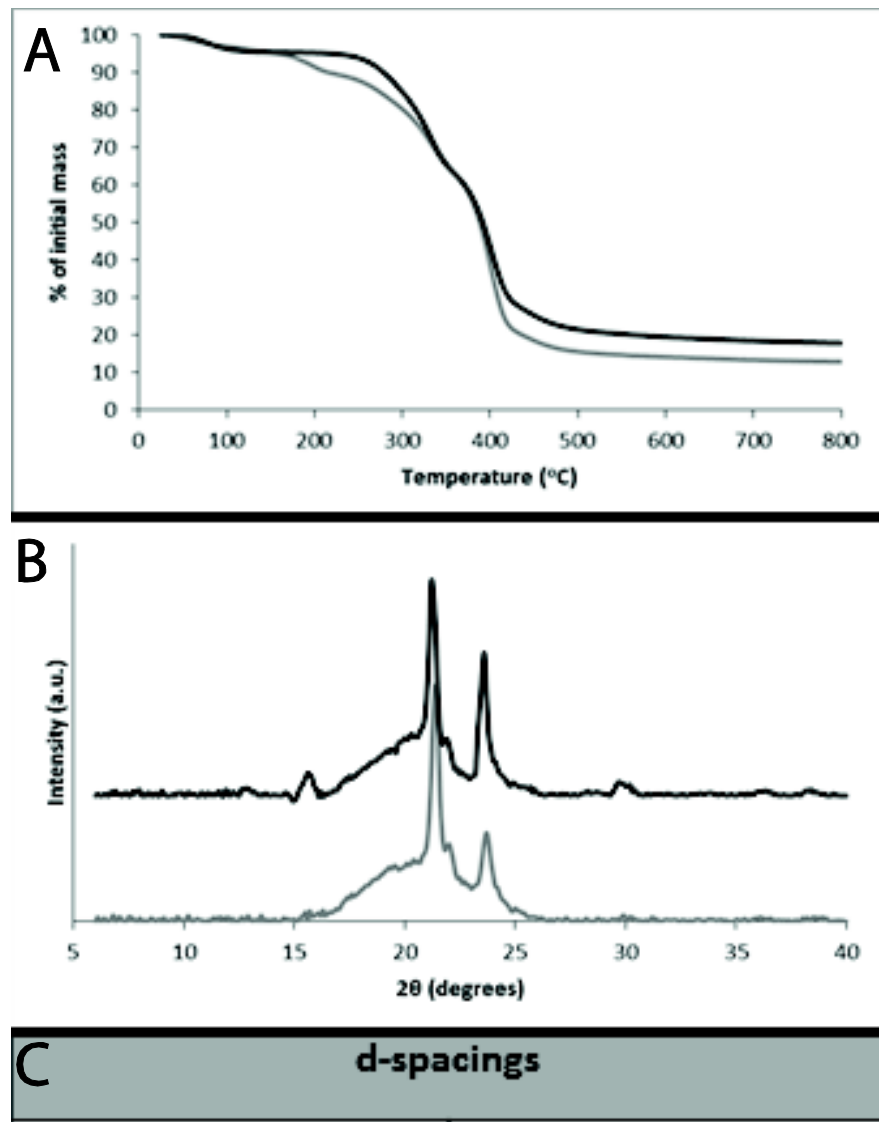

\begin{tabular}{|c|c|c|c}
\multicolumn{2}{|c|}{ Films as cast from HFIP } & \multicolumn{2}{c}{ Methanol treated films } \\
\hline $2 \theta$ & $\begin{array}{c}\text { d-spacing } \\
(\AA)\end{array}$ & $\begin{array}{c}2 \theta \\
\text { (degrees) }\end{array}$ & $\begin{array}{c}\text { d-spacing } \\
(\AA)\end{array}$ \\
\hline 19.42 & 4.57 & 15.63 & 5.67 \\
21.45 & 4.14 & 20.37 & 4.36 \\
23.65 & 3.76 & 21.23 & 4.18 \\
& & 23.47 & 3.79 \\
& & 29.69 & 3.00 \\
\hline
\end{tabular}

Figure S3. SI for PCL-50 films. A) TGA mass loss profiles of films as cast (grey line) and after methanol treatment (black line). B) XRD spectra of films as cast (grey line) and after methanol treatment (black line). C) Positions of XRD peaks and d-spacings determined using Jade 9 XRD Pattern Processing software. 

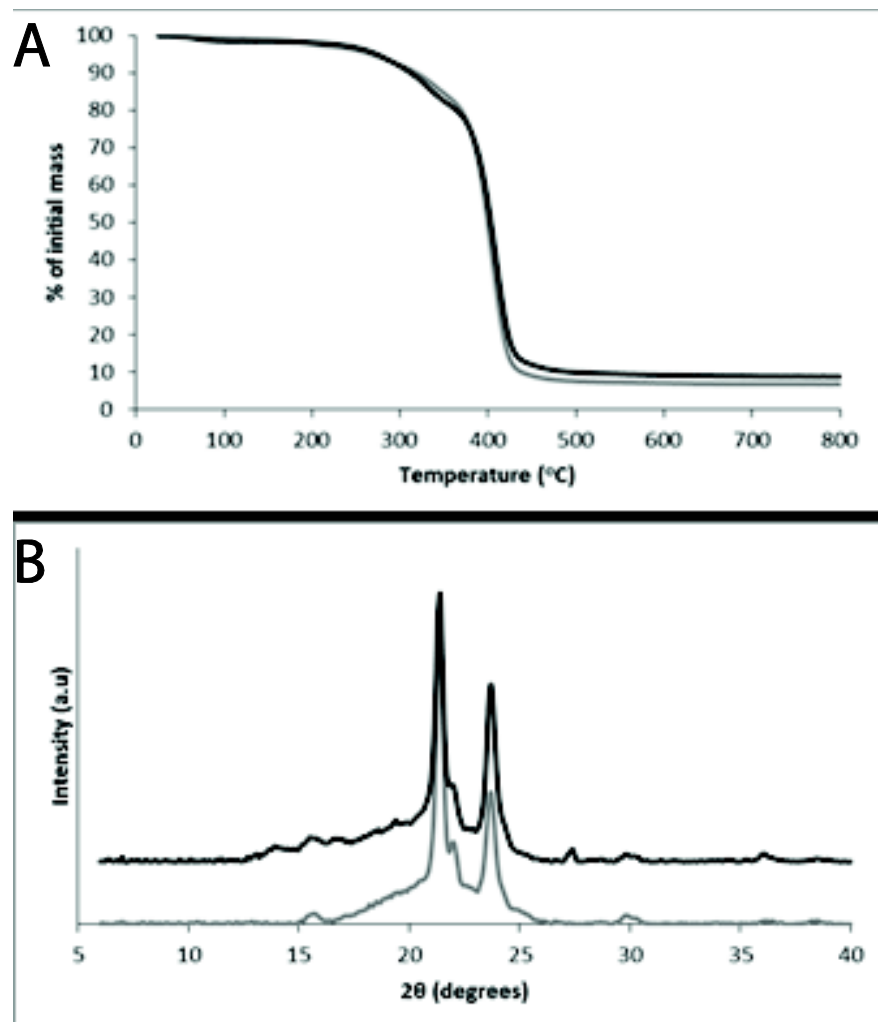

\begin{tabular}{|c|c|c|c|}
\hline \multicolumn{4}{|c|}{ d-spacings } \\
\hline \multicolumn{3}{|l|}{ Films as cast from HFIP } & \multicolumn{2}{l|}{ Methanol treated films } \\
\hline $2 \theta$ & $\begin{array}{c}\text { d-spacing } \\
(\AA)\end{array}$ & $\begin{array}{c}2 \theta \\
\text { (degrees) }\end{array}$ & $\begin{array}{c}\text { d-spacing } \\
(\AA)\end{array}$ \\
\hline 15.63 & 5.67 & 15.63 & 5.67 \\
21.25 & 4.18 & 21.34 & 4.16 \\
23.61 & 3.77 & 23.65 & 3.76 \\
29.83 & 2.99 & 29.69 & 3.00
\end{tabular}

Figure S4. SI for PCL-75 films. A) TGA mass loss profiles of films as cast (grey line) and after methanol treatment (black line). B) XRD spectra of films as cast (grey line) and after methanol treatment (black line). C) Positions of XRD peaks and d-spacings determined using Jade 9 XRD

Pattern Processing software. 

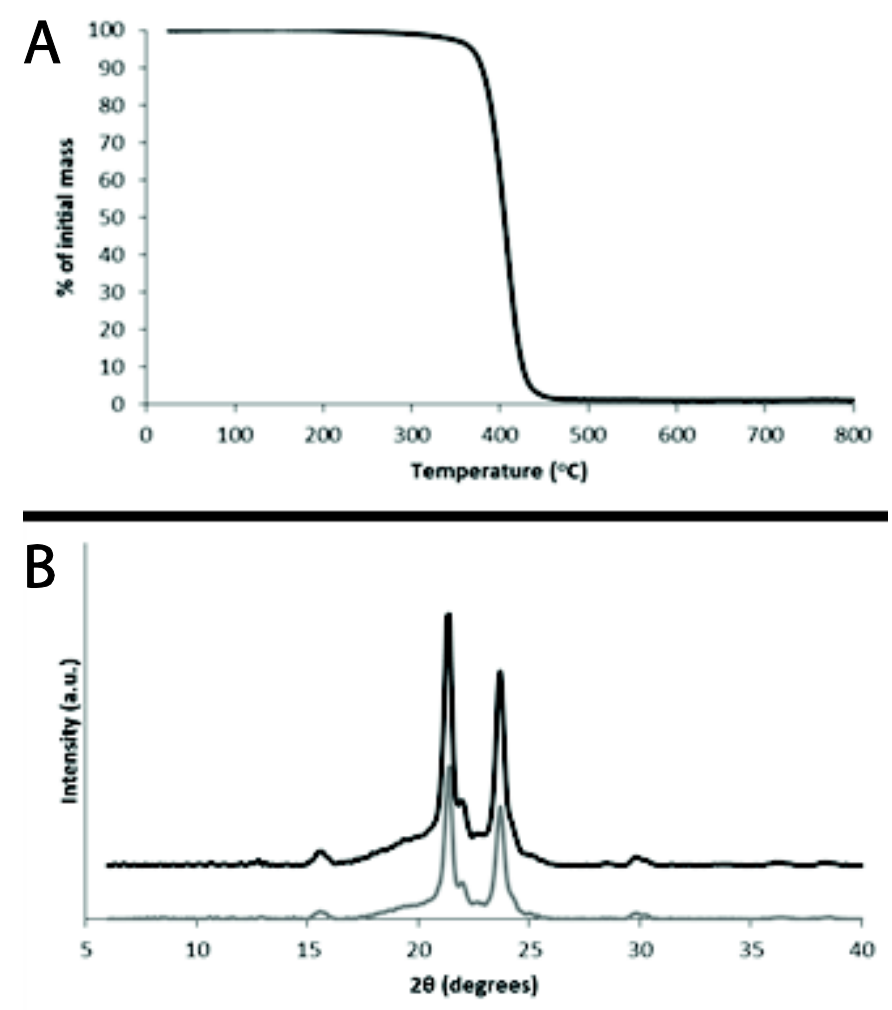

\begin{tabular}{|c|c|c|c}
\hline \multicolumn{4}{|c}{ d-spacings } \\
\hline \multicolumn{3}{|l}{ Films as cast from HFIP } & \multicolumn{2}{l}{ Methanol treated films } \\
\hline $2 \theta$ & $\begin{array}{c}\text { d-spacing } \\
(\AA)\end{array}$ & $\begin{array}{c}2 \theta \\
\text { (degrees) }\end{array}$ & $\begin{array}{c}\text { d-spacing } \\
(\AA)\end{array}$ \\
\hline 15.56 & 5.69 & 15.63 & 5.67 \\
21.34 & 4.16 & 21.56 & 4.11 \\
23.65 & 3.76 & 23.65 & 3.76 \\
29.83 & 2.99 & 29.69 & 3.00 \\
& & &
\end{tabular}

Figure S5. SI for PCL-100 films. A) TGA mass loss profiles of films as cast (grey line) and after methanol treatment (black line). B) XRD spectra of films as cast (grey line) and after methanol treatment (black line). C) Positions of XRD peaks and d-spacings determined using Jade 9 XRD

Pattern Processing software. 

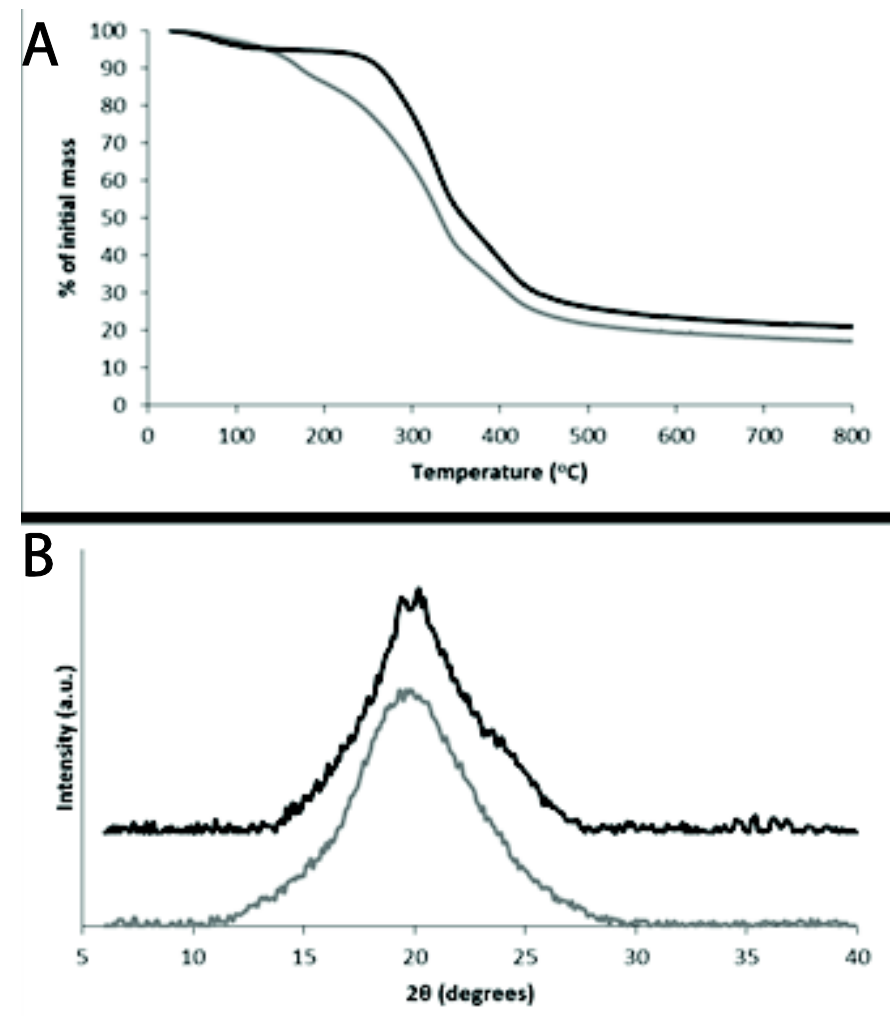

\begin{tabular}{l|c|c|c}
\hline \multicolumn{4}{l}{ d-spacings } \\
\multicolumn{2}{l}{ Films as cast from HFIP } & \multicolumn{2}{l}{ Methanol treated films } \\
\hline $2 \theta$ & $\begin{array}{c}\text { d-spacing } \\
(\AA)\end{array}$ & $2 \theta$ & $\begin{array}{c}\text { d-spacing } \\
\text { (degrees) }\end{array}$ \\
(degrees) & 4.54 & 19.38 & 4.58 \\
\hline 19.53 & & 20.20 & 4.39
\end{tabular}

Figure S6. SI for TPU-25 films. A) TGA mass loss profiles of films as cast (grey line) and after methanol treatment (black line). B) XRD spectra of films as cast (grey line) and after methanol treatment (black line). C) Positions of XRD peaks and d-spacings determined using Jade 9 XRD Pattern Processing software. 

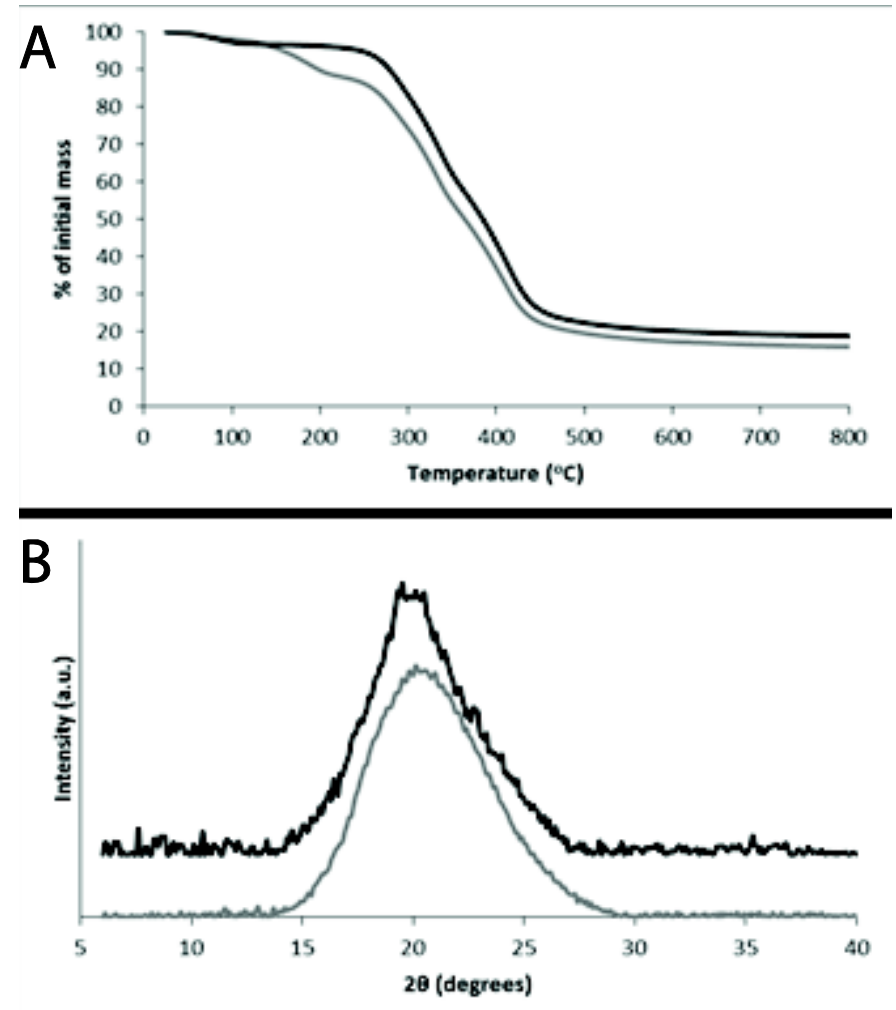

\begin{tabular}{|c|c|c|c|}
\hline \multicolumn{4}{|c}{ d-spacings } \\
\hline \multicolumn{2}{|l|}{ Films as cast from HFIP } & \multicolumn{2}{l}{ Methanol treated films } \\
\hline $2 \theta$ & $\begin{array}{c}\text { d-spacing } \\
(\AA)\end{array}$ & $\begin{array}{c}2 \theta \\
\text { (degrees) }\end{array}$ & $\begin{array}{c}\text { d-spacing } \\
(\AA)\end{array}$ \\
\hline 20.04 & 4.43 & 19.38 & 4.58 \\
& 20.20 & 4.39 \\
\hline
\end{tabular}

Figure S7. SI for TPU-50 films. A) TGA mass loss profiles of films as cast (grey line) and after methanol treatment (black line). B) XRD spectra of films as cast (grey line) and after methanol treatment (black line). C) Positions of XRD peaks and d-spacings determined using Jade 9 XRD Pattern Processing software. 

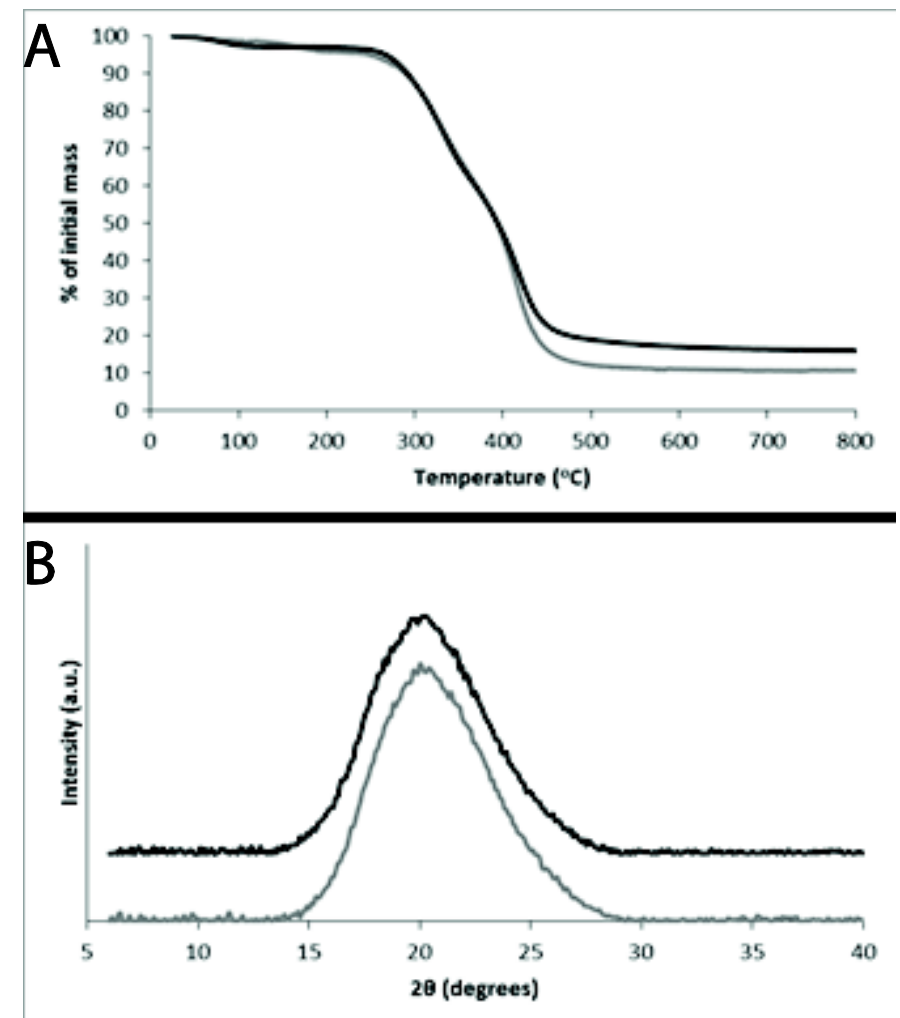

\begin{tabular}{|c|c|c|c|}
\hline \multicolumn{3}{|c|}{ d-spacings } \\
\hline \multicolumn{2}{|l|}{ Films as cast from HFIP } & \multicolumn{2}{l}{ Methanol treated films } \\
\hline $2 \theta$ & $\begin{array}{c}\text { d-spacing } \\
(\AA)\end{array}$ & $\begin{array}{c}2 \theta \\
\text { (degrees) }\end{array}$ & $\begin{array}{c}\text { d-spacing } \\
(\AA)\end{array}$ \\
\hline 19.88 & 4.46 & 19.38 & 4.58 \\
& 20.20 & 4.39
\end{tabular}

Figure S8. SI for TPU-75 films. A) TGA mass loss profiles of films as cast (grey line) and after methanol treatment (black line). B) XRD spectra of films as cast (grey line) and after methanol treatment (black line). C) Positions of XRD peaks and d-spacings determined using Jade 9 XRD Pattern Processing software. 

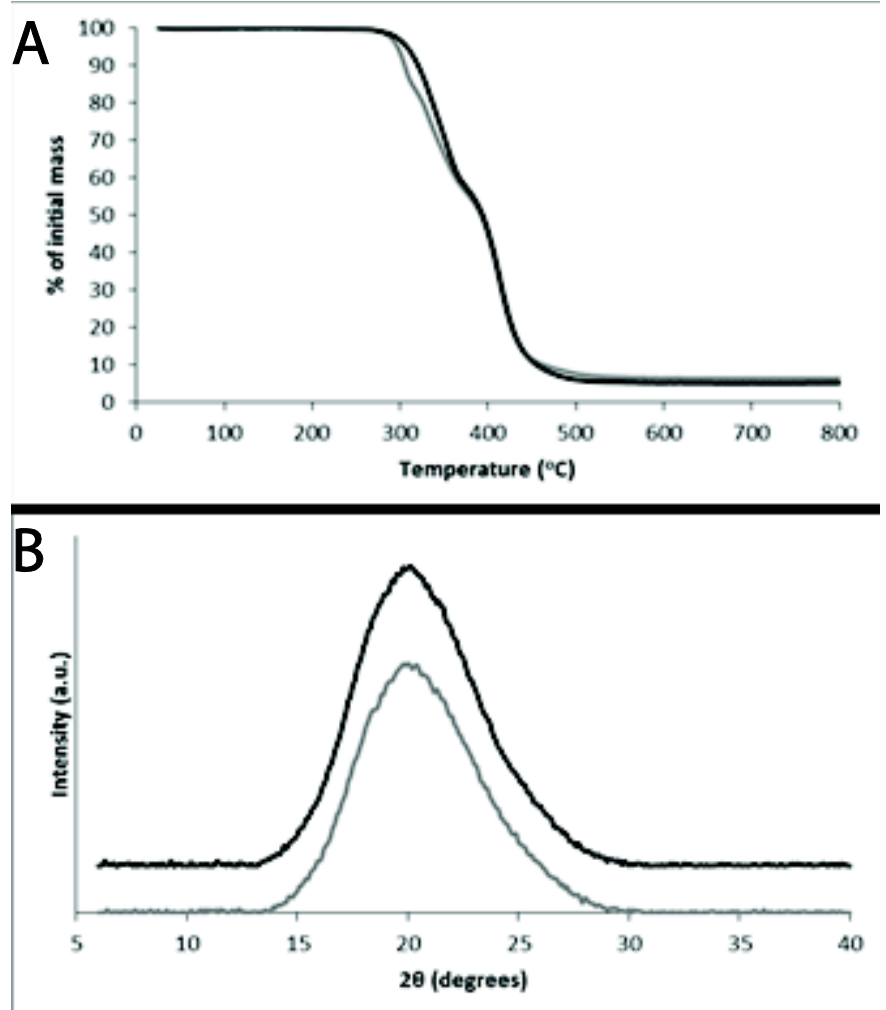

\begin{tabular}{l|c|c|c|}
\hline \multicolumn{4}{|c}{ d-spacings } \\
\hline \multicolumn{3}{|l|}{ Films as cast from HFIP } & \multicolumn{2}{l}{ Methanol treated films } \\
\hline $2 \theta$ & $\begin{array}{c}\text { d-spacing } \\
(\AA)\end{array}$ & $\begin{array}{c}2 \theta \\
\text { (degrees) }\end{array}$ & $\begin{array}{c}\text { d-spacing } \\
(\AA)\end{array}$ \\
(degrees) & 4.51 & 19.66 & 4.51 \\
\hline 19.66 &
\end{tabular}

Figure S9. SI for TPU-100 films. A) TGA mass loss profiles of films as cast (grey line) and after methanol treatment (black line). B) XRD spectra of films as cast (grey line) and after methanol treatment (black line). C) Positions of XRD peaks and d-spacings determined using Jade 9 XRD

Pattern Processing software. 

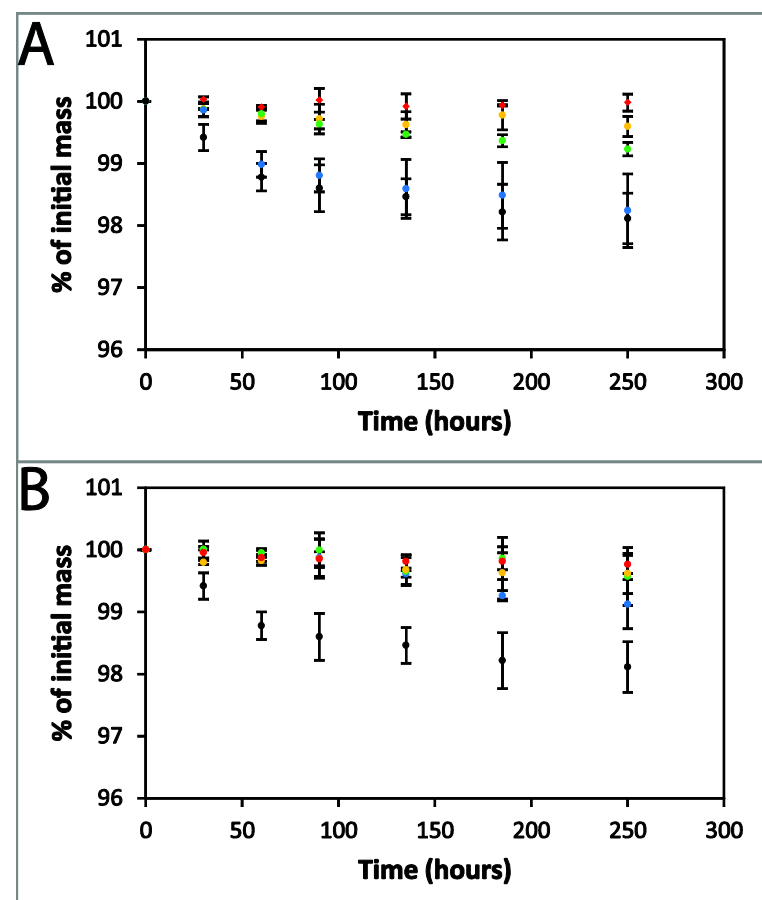

Figure S10. In vitro degradation of the biodegradable films composed of eADF-4(C16) and PCL or TPU in PBS. A: Black) eADF-4(C16); Blue) PCL-25; Green) PCL-50; Yellow) PCL-75; Red) PCL-100. B: Black) eADF-4(C16); Blue) TPU-25; Green) TPU-50; Yellow) TPU-75; Red) TPU-100. 


\section{References:}

[1] D. G. Anderson, J. A. Burdick, R. Langer, Science 2004, 305, 1923.

[2] J. M. Karp, R. Langer, Curr. Opin. Biotechnol. 2007, 18, 454.

[3] A. Khademhosseini, C. Bettinger, J. M. Karp, J. Yeh, Y. Ling, J. Borenstein, J. Fukuda, R. Langer, J. Biomater. Sci. Polym. Ed. 2006, 17, 1221.

[4] D. S. Kohane, R. Langer, Pediatr. Res. 2008, 63, 487.

[5] R. Langer, L. G. Cima, J. A. Tamada, E. Wintermantel, Biomaterials 1990, 11, 738.

[6] N. A. Peppas, R. Langer, Science 1994, 263, 1715.

[7] L. S. Nair, C. T. Laurencin, Prog. Polym. Sci. 2007, 32, 762.

[8] B. D. Ulery, L. S. Nair, C. T. Laurencin, J. Polym. Sci. Pol. Phys. 2011, 49, 832.

[9] B. Kundu, R. Rajkhowa, S. C. Kundu, X. Wang, Adv. Drug. Deliv. Rev. 2012.

[10] S. C. Kundu, B. C. Dash, R. Dash, D. L. Kaplan, Prog. Polym. Sci. 2008, 33, 998.

[11] C. Vepari, D. L. Kaplan, Prog. Polym. Sci. 2007, 32, 991.

[12] R. S. Langer, N. A. Peppas, Biomaterials 1981, 2, 201.

[13] J. G. Hardy, T. R. Scheibel, Prog. Polym. Sci. 2010, 35, 1093.

[14] X. Hu, P. Cebe, A. S. Weiss, F. Omenetto, D. L. Kaplan, Mater. Today 2012, 15, 208.

[15] D. N. Rockwood, R. C. Preda, T. Yucel, X. Wang, M. L. Lovett, D. L. Kaplan, Nat. Protoc. 2011, 6, 1612.

[16] B. Subia, S. C. Kundu, Nanotechnology 2013, 24.

[17] R. Elia, D. R. Newhide, P. D. Pedevillano, G. R. Reiss, M. A. Firpo, E. W. Hsu, D. L.

Kaplan, G. D. Prestwich, R. A. Peattie, J. Biomater. Appl. 2013, 27, 749.

[18] C. Acharya, T. V. Kumary, S. K. Ghosh, S. C. Kundu, J. Biomat. Sci. Polym. Ed. 2009, 20, 543.

[19] X. Q. Wang, T. Yucel, Q. Lu, X. Hu, D. L. Kaplan, Biomaterials 2010, 31, 1025.

[20] T. D. Sutherland, J. H. Young, S. Weisman, C. Y. Hayashi, D. J. Merritt, Annu. Rev.

Entomol. 2010, 55, 171.

[21] F. G. Omenetto, D. L. Kaplan, Nat. Mater. 2012, 11, 273.

[22] J. G. Hardy, L. M. Romer, T. R. Scheibel, Polymer 2008, 49, 4309.

[23] A. Rising, M. Widhe, J. Johansson, M. Hedhammar, Cell. Mol. Life. Sci. 2011, 68, 169.

[24] J. G. Hardy, T. R. Scheibel, Biochem. Soc. Trans. 2009, 37, 677.

[25] J. G. Hardy, T. R. Scheibel, J. Polym. Sci. Polym. Chem. 2009, 47, 3957.

[26] M. Heim, D. Keerl, T. Scheibel, Angew. Chem. Int. Ed. 2009, 48, 3584.

[27] M. Heim, L. Romer, T. Scheibel, Chem. Soc. Rev. 2010, 39, 156.

[28] M. Widhe, J. Johansson, M. Hedhammar, A. Rising, Biopolymers 2012, 97, 468.

[29] G. H. Altman, F. Diaz, C. Jakuba, T. Calabro, R. L. Horan, J. S. Chen, H. Lu, J. Richmond, D. L. Kaplan, Biomaterials 2003, 24, 401.

[30] A. Leal-Egaña, T. Scheibel, Biotechnol. Appl. Bioc. 2010, 55, 155.

[31] X. X. Xia, Z. G. Qian, C. S. Ki, Y. H. Park, D. L. Kaplan, S. Y. Lee, PNAS 2010, 107, 14059.

[32] S. Winkler, D. Wilson, D. L. Kaplan, Biochemistry 2000, 39, 12739.

[33] S. Szela, P. Avtges, R. Valluzzi, S. Winkler, D. Wilson, D. Kirschner, D. L. Kaplan, Biomacromol. 2000, 1, 534.

[34] A. J. Mieszawska, N. Fourligas, I. Georgakoudi, N. M. Ouhib, D. J. Belton, C. C. Perry, D. L. Kaplan, Biomaterials 2010, 31, 8902.

[35] C. W. P. Foo, S. V. Patwardhan, D. J. Belton, B. Kitchel, D. Anastasiades, J. Huang, R. R. Naik, C. C. Perry, D. L. Kaplan, PNAS 2006, 103, 9428. 
[36] S. Wohlrab, S. Muller, A. Schmidt, S. Neubauer, H. Kessler, A. Leal-Egaña, T. Scheibel, Biomaterials 2012, 33, 6650.

[37] D. Huemmerich, C. W. Helsen, S. Quedzuweit, J. Oschmann, R. Rudolph, T. Scheibel, Biochemistry 2004, 43, 13604.

[38] M. Schmidt, L. Romer, M. Strehle, T. Scheibel, Biotechnol. Lett. 2007, 29, 1741.

[39] K. Spiess, A. Lammel, T. Scheibel, Macromol. Biosci. 2010, 10, 998.

[40] A. Lammel, M. Schwab, M. Hofer, G. Winter, T. Scheibel, Biomaterials 2011, 32, 2233.

[41] A. Lammel, M. Schwab, U. Slotta, G. Winter, T. Scheibel, ChemSusChem 2008, 1, 413.

[42] C. Blüm, T. Scheibel, BioNanoSci 2012, 2, 67.

[43] K. Spiess, R. Ene, C. D. Keenan, J. Senker, F. Kremer, T. Scheibel, J. Mater. Chem. 2011, 21, 13594.

[44] S. Wohlrab, K. Spiess, T. Scheibel, J. Mater. Chem. 2012, 22, 22050.

[45] A. Leal-Egaña, T. Scheibel, J. Mater. Chem. 2012, 22, 14330.

[46] M. A. Woodruff, D. W. Hutmacher, Prog. Polym. Sci. 2010, 35, 1217.

[47] J. M. Anderson, Q. Zhao, M. Brunstedt, R. Marchant, A. Hiltner, Abstr. Pap. Am. Chem. Soc. 1990, 199, 156.

[48] D. J. Martin, G. F. Meijs, P. A. Gunatillake, S. P. Yozghatlian, G. M. Renwick, J. Appl. Polym. Sci. 1999, 71, 937.

[49] W. K. Ward, E. P. Slobodzian, K. L. Tiekotter, M. D. Wood, Biomaterials 2002, 23, 4185. [50] L. F. Drummy, D. M. Phillips, M. O. Stone, B. L. Farmer, R. R. Naik, Biomacromol. 2005, 6, 3328.

[51] O. Rathore, D. Y. Sogah, J. Am. Chem. Soc. 2001, 123, 5231.

[52] H. Saito, R. Tabeta, A. Shoji, T. Ozaki, I. Ando, Macromol. 1983, 16, 1050.

[53] S. Arnott, S. D. Dover, A. Elliott, J. Mol. Biol. 1967, 30, 201.

[54] A. Baji, S. C. Wong, T. X. Liu, T. C. Li, T. S. Srivatsan, J. Biomed. Mater. Res. B. 2007, $81 B, 343$.

[55] J. C. Jeong, J. Lee, K. Cho, J. Control. Rel. 2003, 92, 249.

[56] J. Candiello, M. Balasubramani, E. M. Schreiber, G. J. Cole, U. Mayer, W. Halfter, H. Lin, FEBS J. 2007, 274, 2897.

[57] M. Bouvier, A. S. Chawla, I. Hinberg, J. Biomed. Mater. Res. 1991, 25, 773.

[58] M. C. Tanzi, S. Fare, P. Petrini, J. Biomater. Appl. 2000, 14, 325.

[59] L. Visai, S. Rindi, P. Speziale, P. Petrini, S. Fare, M. C. Tanzi, J. Biomater. Appl. 2002, 16, 191.

[60] B. D. Angeline, A. Hiltner, J. M. Anderson, Degrad. Mater. 1990, 295.

[61] C. Allmeling, A. Jokuszies, K. Reimers, S. Kall, C. Y. Choi, G. Brandes, C. Kasper, T.

Scheper, M. Guggenheim, P. M. Vogt, Cell Prolif. 2008, 41, 408.

[62] C. Allmeling, A. Jokuszies, K. Reimers, S. Kall, P. M. Vogt, J. Cell. Mol. Med. 2006, 10, 770.

[63] J. W. Kuhbier, K. Reimers, C. Kasper, C. Allmeling, A. Hillmer, B. Menger, P. M. Vogt, C. Radtke, J. Biomed. Mater. Res. B 2011, 97B, 381.

[64] C. Radtke, C. Allmeling, K. H. Waldmann, K. Reimers, K. Thies, H. C. Schenk, A. Hillmer, M. Guggenheim, G. Brandes, P. M. Vogt, PLOS One 2011, 6.

[65] Y. Cao, B. Wang, Int. J. Mol. Sci. 2009, 10, 1514.

[66] Y. Wang, D. D. Rudym, A. Walsh, L. Abrahamsen, H. J. Kim, H. S. Kim, C. Kirker-Head, D. L. Kaplan, Biomaterials 2008, 29, 3415. 
[67] C. X. Lam, D. W. Hutmacher, J. T. Schantz, M. A. Woodruff, S. H. Teoh, J. Biomed. Mater. Res. A 2009, 90, 906.

[68] A. Brandwood, G. F. Meijs, P. A. Gunatillake, K. R. Noble, K. Schindhelm, E. Rizzardo, J. Biomat. Sci. Polym. Ed. 1994, 6, 41.

[69] M. R. Brunstedt, J. M. Anderson, K. L. Spilizewski, R. E. Marchant, A. Hiltner, Biomaterials 1990, 11, 370.

[70] R. W. Hergenrother, H. D. Wabers, S. L. Cooper, Biomaterials 1993, 14, 449.

[71] W. Y. J. Kao, Q. H. Zhao, A. Hiltner, J. M. Anderson, J. Biomed. Mater. Res. 1994, $28,73$.

[72] G. Peluso, O. Petillo, L. Ambrosio, L. Nicolais, J. Mater. Sci. Mater. Med. 1994, 5, 738.

[73] E. M. Pritchard, X. Hu, V. Finley, C. K. Kuo, D. L. Kaplan, Macromol. Biosci. 2013.

[74] E. M. Pritchard, P. B. Dennis, F. Omenetto, R. R. Naik, D. L. Kaplan, Biopolymers 2012, 97, 479.

[75] A. Leal-Egaña, G. Lang, C. Mauerer, J. Wickinghoff, M. Weber, S. Geimer, T. Scheibel, Adv. Eng. Mater. 2012, 14, B67.

[76] M. S. Kim, Y. N. Shin, M. H. Cho, S. H. Kim, S. K. Kim, Y. H. Cho, G. Khang, I. W. Lee, H. B. Lee, Tiss. Eng. 2007, 13, 2095.

[77] A. R. Murphy, D. L. Kaplan, J. Mater. Chem. 2009, 19, 6443.

[78] F. Grinnell, Int. Rev. Cytol. 1978, 53, 65.

[79] E. A. Vogler, Adv. Coll. Int. Sci. 1998, 74, 69.

[80] E. A. Vogler, J. Biomater. Sci., Polymer Edition 1999, 10, 1015. 